\title{
Case Report-
}

\section{Septicemia Associated with Hafnia alvei in Laying Hens}

\author{
F. Real, ${ }^{\mathrm{A}}$ A. Fernández, ${ }^{\mathrm{B}}$ F. Acosta, ${ }^{\mathrm{A}}$ B. Acosta, ${ }^{\mathrm{A}}$ \\ P. Castro, ${ }^{B}$ S. Déniz, ${ }^{A}$ and J. Orós ${ }^{B}$ \\ ${ }^{A}$ Unit of Infectious Diseases \\ ${ }^{B}$ Unit of Histology and Pathological Anatomy \\ Veterinary Faculty, C/. Francisco Inglott Artiles, 12A, \\ Universidad de Las Palmas de Gran Canaria, 35071, Las Palmas de Gran Canaria, Spain
}

Received 21 October 1996

\begin{abstract}
SUMMARY. In the present work Hafnia alvei was isolated from laying hens displaying a reduction in egg production, loss of appetite, opisthotonus, and death. Multifocal necrotizing hepatitis and splenitis were the most prominent lesions. The organism was identified microbiologically. Laying hens were experimentally inoculated by the oral and intraperitoneal route to show the pathogenicity of the organism. A very similar clinicopathologic effect resulted from this trial. Several experimentally infected laying hens died due to septicemia. We conclude that $H$. alvei may cause a septicemia similar to that reportedly caused by Salmonella spp. in avian species.
\end{abstract}

RESUMEN. Reporte de Caso-Septicemia asociada con Hafnia alvei en gallinas ponedoras.

Se aisló Hafnia alvei de gallinas ponedoras que mostraron una baja en producción, pérdida del apetito, opistótonos y mortalidad. Las lesiones más prominentes fueron esplenitis y hepatitis necrosante multifocal. El organismo fue identificado microbiológicamente. Ponedoras comerciales fueron inoculadas experimentalmente por la ruta oral e intraperitoneal con el objeto de comprobar la patogenicidad del microorganismo. Después de la inoculación, se observó un efecto clínicopatológico similar. Varias ponedoras infectadas experimentalmente murieron debido a la septicemia. Concluimos que $H$. alvei puede causar una septicemia similar a la reportada por Salmonella spp. en las aves.

Key words: laying hens, Hafnia alvei, septicemia, clinicopathologic picture, immunoperoxidase labeling, experimental challenge

Abbreviation: PBS $=$ phosphate-buffered saline

Hafnia alvei is found in natural environments such as soil, sewage, and water $(1,17)$. This organism has been isolated from different foods, including cow's milk (21), honey (18), corned beef (15), and hard goat cheese (22), where it affects the microbiologic quality of these food items. Moreover, this microorganism has been reported to cause hemorrhagic septicemia in rainbow trout (6) and has been isolated from aborted equine fetuses $(14,24)$, as well as from goats suffering from caprine pneumonia (19) and cows with mastitis (2). In humans $H$. alvei has been associated with gastroenteritis, septicemia, and urinary infections
$(11,17)$. However, to our knowledge, $H$. alvei has not been reported to be associated with any clinicopathologic effects in poultry. The role of this organism as a primary pathogen has been questioned in most reported cases; it has generally been considered to be an opportunistic pathogen occurring with other underlying illnesses or predisposing factors (17).

Septicemic lesions caused by Hafnia spp. in several species $(10,16)$ are very similar to those produced by Salmonella spp. Hafnia spp. are difficult to differentiate microbiologically from other common pathogens in poultry. Infections caused by Salmonella spp. may be particularly 
problematic because colonies of Hafnia in cultures may resemble those of Salmonella on routine isolation media and cause confusion in confirming the identities of these organisms (17); Hafnia cultures reportedly are often agglutinated by Salmonella $\mathrm{O}$ antisera $(4,8)$. Furthermore, there are no selective enrichment broth media for the isolation of Hafria organisms. Distinguishing Hafnia spp. from Enterobacter aerogenes, Enterobacter gergoviae, Serratia spp., and Yokenella regensburgei may also be difficult (17).

This report describes a field case occurring in a commercial laying hen flock displaying sudden loss of productivity and acute mortality with clinicopathologic septicemia from which $H$. alve $i$ was isolated and identified.

\section{MATERIALS AND METHODS}

Ten chickens from a poultry farm with 3000 laying hens were submitted to the Veterinary Diagnostic Service (Veterinary Faculty, University of Las Palmas de Gran Canaria, Spain) for necropsy. The clinical history consisted of a daily mortality of 40-50 birds with loss of appetite, as well as reduction in egg production but without problems with eggshells or internal quality of the eggs. Deaths also occurred suddenly with no other previous signs. The flock underwent a good disease prevention program, including vaccinations against avian infectious bronchitis, Newcastle disease, avian encephalomyelitis, Gumboro disease, and Marek's disease.

Affected birds were sacrificed at the Pathological Anatomy Laboratory of the Veterinary Faculty (University of Las Palmas de Gran Canaria), where the necropsies were carried out. Serum samples obtained from these birds were collected and analyzed by hemagglutination inhibition against Newcastle disease.

Lungs, trachea, heart, liver, spleen, kidney, proventriculus, gizzard, intestines, and brain samples were fixed in $10 \%$ neutral buffered formalin and routinely embedded in paraffin. Four-micrometer-thick tissue sections were stained with hematoxylin and eosine. Selected sections were also stained using Gram stain and periodic acid-Schiff techniques.

Samples of liver, lung, kidney, spleen, small intestine, and cecum also were taken for microbiologic study. These were cultured separately on blood agar (Difco), MacConkey agar (Difco), and mycobiotic agar (Difco), and incubated at $37 \mathrm{C}$ under aerobic and anaerobic conditions for $24 \mathrm{hr}$. Samples from the same tissues were also cultured for mycoplasma using SP4 (23) and Friis (5) broth and agar media supplemented with $20 \%$ horse serum. Penicillin (500 $\mathrm{IU} / \mathrm{ml}$ ) was added as a bacterial inhibitor. These me-
Table 1. Results of the experimental inoculation of laying hens with Hafnia alvei (187/95).

\begin{tabular}{ccccc}
\hline \multicolumn{3}{c}{$\begin{array}{c}\text { Route } \\
\text { of }\end{array}$} & & $\begin{array}{c}\text { Bacte- } \\
\text { rial } \\
\text { Ani- } \\
\text { ino- } \\
\text { mal } \\
\text { no. }\end{array}$ \\
cul- & $\begin{array}{c}\text { ationi- } \\
\text { atiol }\end{array}$ & $\begin{array}{c}\text { cal } \\
\text { signs }\end{array}$ & $\begin{array}{c}\text { Result of inoculation } \\
\text { (days postinfection) }\end{array}$ & $\begin{array}{c}\text { la- } \\
\text { tion }^{B}\end{array}$ \\
\hline 1 & IP & + & Death (6) & + \\
2 & IP & + & Slaughtered (13) & + \\
3 & IP & + & Death (8) & + \\
4 & O & + & Death (9) & + \\
5 & O & + & Slaughtered (24) & + \\
6 & O & + & Slaughtered (24) & + \\
$C^{A}$ & IP & - & Slaughtered (13 and 24) & - \\
$C^{C}$ & O & - & Slaughtered (13 and 24) & - \\
\hline
\end{tabular}

${ }^{\mathrm{A}} \mathrm{IP}=$ intraperitoneal, $\mathrm{O}=$ oral, $\mathrm{C}=$ control animals.

${ }^{\mathrm{B} I s o l a t i o n}$ of $H$. alvei from kidney, spleen, liver, and intestines.

CTwo animals were used.

dia were incubated at $37 \mathrm{C}$ in a moist atmosphere for at least a week before cultures were considered negative.

The isolated bacteria (number 187/95) were identified by various tests, using previously described methods (20). Biochemical strips (API 20E, 20100; Bio Mérieux, Lyon, France) were also used. To ensure the identification of the isolated bacteria as $H$. alvei $187 / 95$, a Hafnia-specific bacteriophage test (7) using phage 1672 (ATCC) was applied. This test allows a rapid differentiation of Hafnia from Salmonella organisms; this distinction is usually a problem for identification. Different doses of phage 1672, from $10^{\circ}$ to $10^{-6}$, were mixed with the bacteria (187/95) on nutrient agar plates (7) and the results were compared with those obtained with other similar microorganisms isolated in our laboratory, such as Salmonella spp. (96/93 and 261/94), Enterobacter cloacae (63/94), Klebsiella oxytoca (122/96), and Yersinia sp. (68/96). Phage 1672 should only show specific plaques of lysis with Hafnia strains (7).

As $H$. alvei, to our knowledge, has not previously been reported in poultry, the isolated bacteria (187/ 95) identified as $H$. alvei was prepared for a challenge trial, as is shown in Table 1 . The trial was conducted using six 30-wk-old hens (three were inoculated orally and three were inoculated intraperitoneally) with a dose of $3 \times 10^{8}$ organisms. Four additional hens were used as controls; two hens were inoculated orally and two were inoculated intraperitoneally with $1 \mathrm{ml}$ of sterile saline solution each. The source of these birds was a healthy but not pathogen-free flock that had shown no illness for at least 3 yr. Birds were killed following the schedule shown in Table 1. Necropsies were performed and samples were taken for 
microbiologic, histopathologic, and immunohistochemical study.

To demonstrate the association of the isolated bacteria with lesions in the affected chickens, an immunohistochemical method (12) was used with a polyclonal antiserum against $H$. alvei $187 / 95$ raised in two rabbits. Each rabbit was injected subcutaneously twice with $2 \mathrm{ml}$ of inoculum; the inoculum was delivered by multiple (10 points) doses in separate sites. The inoculum consisted of $1 \mathrm{ml}$ of sterile saline solution containing $H$. alvei $187 / 95\left(10^{8}\right.$ cells/ $\mathrm{ml}$ ) and $1 \mathrm{ml}$ of incomplete Freund's adjuvant. A second injection was given 6 wk after the first, and both rabbits were bled 8 wk after the first boost (9).

For immunohistochemical labeling, sections were dewaxed and immersed in $3 \% \mathrm{H}_{2} \mathrm{O}_{2}$ in absolute methanol for $30 \mathrm{~min}$. The sections were then rinsed in phosphate-buffered saline (PBS) and placed in a

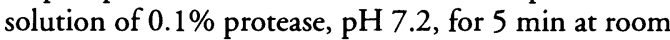
temperature. The sections were washed three times in PBS, blocked with 5\% normal goat serum for 30 min, and exposed to polyclonal antiserum against $H$. alvei applied at dilutions ranging from $1: 100$ to 1:1200 and incubated for $2 \mathrm{hr}$. The sections were rinsed in PBS and incubated for $30 \mathrm{~min}$ with a 1:5 dilution of biotinylated antibody to rabbit IgG raised in goat (Kit LSAB; Dako, Burlingame, CA). All incubations were at room temperature. After rinsing in PBS the sections were exposed to 3-amino-9-ethylcarbazole (Sigma, St Louis, MO) for $5 \mathrm{~min}$. They were then counterstained with Mayer's hematoxylin and mounted using an aqueous mounting medium (Immumount; Shandon, Pittsburgh, PA). Hepatic tissues from avian species naturally infected with Salmonella spp. were used as positive control tissues for Salmonella spp. infection. Negative controls consisted of a polyclonal antiserum against Salmonella arizonae kindly supplied by Dr. J. T. Meehan (13) from the National Animal Disease Center (Ames, IA), and also the substitution of normal goat serum, PBS, or nonrelated antisera for the primary antibody (anti- $H$. alvei). Tissues from several noninfected avian species were also used as negative controls.

\section{RESULTS}

Pathologic results. At necropsy, the most significant lesions in the naturally infected chickens were in the liver, which was enlarged with numerous randomly scattered whitish-yellow foci, 4-5 $\mathrm{mm}$ in diameter, throughout the parenchyma. A diffuse thickening of the intestinal wall with catarrhal exudate on the mucosal surface and splenomegaly (twice the normal size) were also observed. No other gross lesions were seen in the necropsied chickens.
Histologic changes in these naturally infected chickens consisted of a severe multifocal necrotizing hepatitis, with abundant cell debris and infiltration of heterophils associated with the necrotic areas (Fig. 1). Large numbers of gramnegative rods were found closely associated with these hepatic lesions. Disruption of centrilobular hepatocellular cords and multiple venous thrombi were also observed. A severe multifocal necrotizing splenitis was also seen associated with small embolic bacterial colonies. Hyperemia of the intestines and diffuse catarrhal enteritis with loss of epithelial cells, heterophils infiltrating the lamina propria, and thrombi containing bacterial colonies were noted. No relevant microscopic lesions were seen in other organs.

A strong immunoperoxidase red labeling of bacteria was clearly detected using the anti- $H$. alvei rabbit antiserum at a dilution of 1:500. Immunoreactivity was particularly intense around the edges of the necrotic areas of liver (Fig. 1) and spleen. Specific granular immunoperoxidase labeling was also detected in the venous thrombi of the liver, associated with bacteria. Thrombi containing bacterial colonies in vessels of the intestinal lamina propria were also positive.

Serologic and microbiological results. All the affected chickens were detected with high hemagglutination inhibition titers (between 1:256 and 1:5120) against Newcastle disease.

The organism grown on the media was a gram-negative rod that produced small lactosenegative colonies on MacConkey agar. These bacteria were identified as $H$. alvei with the profile 4105112 in the API $20 \mathrm{E}$ system. This bacteria was isolated from every affected tissue; no other bacteria were isolated from all tissues. With some tests this organism can be distinguished from other bacteria (20) such as Salmonella spp., Serratia spp., and Edwarsiella spp. The isolated bacteria may be confused with Yersinia ruckeri.

Phage 1672 on nutrient agar plates only lysed the bacteria $187 / 95$. The phage did not lyse any bacteria other than Hafnia sp. When a $10^{-6}$ dose of phage was used, four clear plaques of lysis with a diameter of 1-2 mm were observed, ensuring that the organism (187/95) was Hafria sp. 

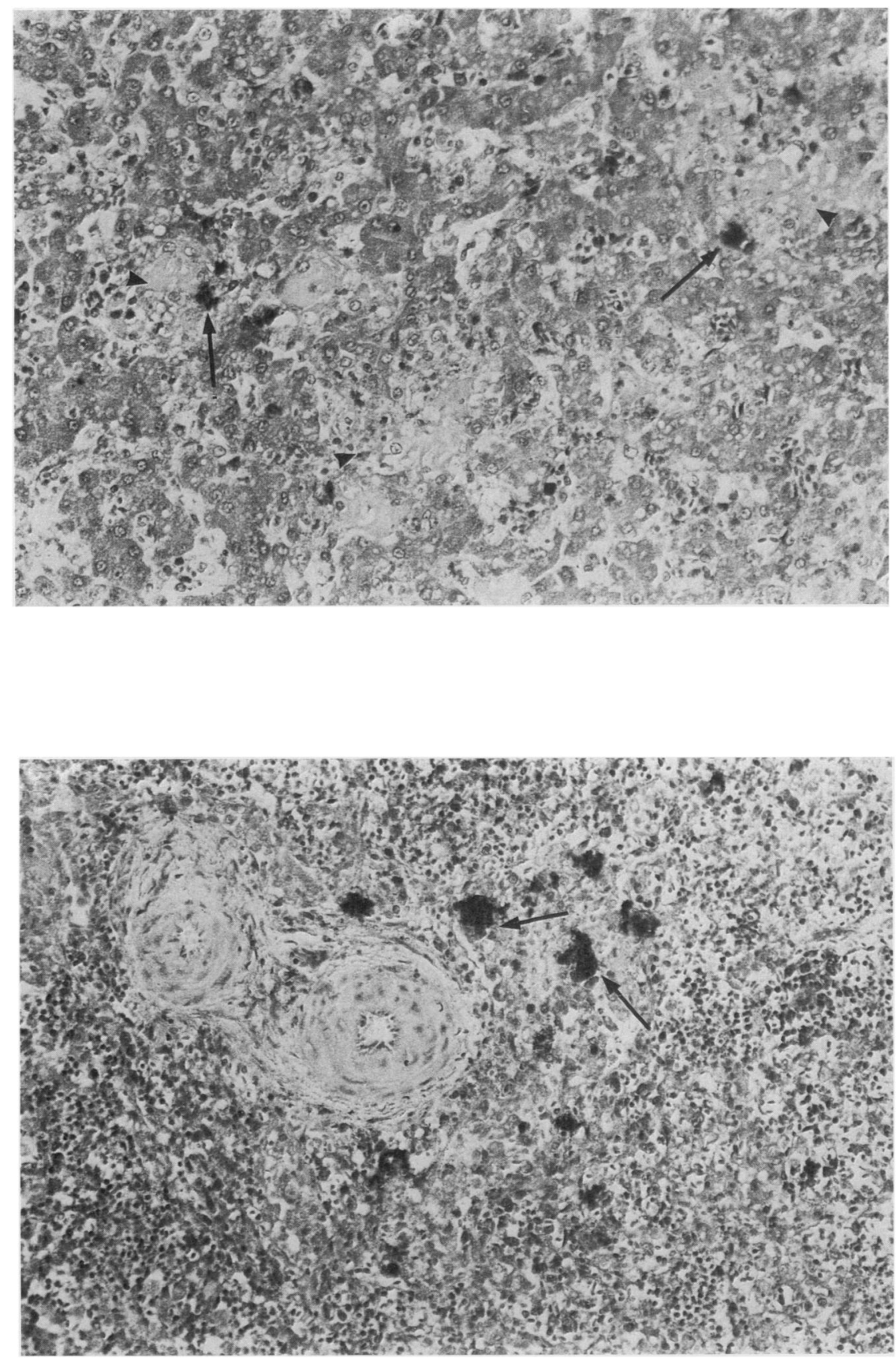

2

Fig. 1. Liver from a chicken naturally infected with Hafnia alvei. Immunoperoxidase labeling of bacteria (arrows) using anti-H. alvei rabbit serum. Note also the severe multifocal necrotizing hepatitis (arrowheads). Dako LSAB kits were used (see Materials and Methods). 20×.

Fig. 2. Spleen from a chicken experimentally infected by oral inoculation with Hafnia alvei. Immunoperoxidase labeling of bacteria using anti- $H$. alvei rabbit serum (arrows). Dako LSAB kits were used (see Materials and Methods). 20X. 
Experimental results. Chickens from the challenge exposure showed clinical signs with opisthotonus, a sporadic reduction in egg production compared with the control birds, and diarrhea about 7 days after inoculation, and similar gross lesions to those that were described above in naturally infected chickens. The liver was enlarged and showed whitish-yellow foci, $5 \mathrm{~mm}$ in diameter, throughout the parenchyma. Splenomegaly was also noted and enteritis was particularly evident in chickens inoculated orally. No macroscopic lesions were found in other organs.

Histologic changes included a severe multifocal necrotizing hepatitis in dead chickens (nos. 1, 3, and 4; Table 1) with infiltration of heterophils around the necrotic foci associated with large numbers of bacterial rods. The spleen showed a severe multifocal necrotizing splenitis associated with large numbers of gramnegative rods. Numerous bacterial emboli were observed in kidneys, lungs, pleura, central nervous system, and small vessels of the myocardium, but no associated inflammation was seen in these organs. Chickens inoculated by the intraperitoneal route (nos. 1 and 3; Table 1) also showed bacterial emboli in the intestinal serosa and infiltration of heterophils in this area. A diffuse catarrhal enteritis with thrombi containing bacterial colonies in the vessels of the lamina propria was observed in one bird inoculated orally (no. 4; Table 1). No microscopic lesions were seen in other organs. No significant lesions were detected in noninfected control chickens.

Immunohistochemical results were similar to those observed in naturally infected chickens. Positive immunoreactivity, using the anti- $H$. alvei rabbit serum at a dilution of 1:500, was strong in the necrotic areas of liver and spleen (Fig. 2). Bacterial emboli in vessels of kidneys, lungs, pleura, central nervous system, and cardiac muscle were also labeled. One orally inoculated chicken showed immunoreactivity in the thrombi of the intestinal lamina propria. A weak reaction was also observed in thrombi of the intestinal vessels (no. 1; Table 1). No immunoreaction was detected when $S$. arizonae antiserum (13), normal serum, or PBS were used as primary antibody on tissues naturally or experimentally infected with $H$. alvei. Furthermore, $H$. alvei antiserum (187/95) reacted immunohistochemically negative on tissues with infected Salmonella spp.
Hafnia alvei was reisolated from all experimental chickens (Table 1).

\section{DISCUSSION}

Microbiologically, the organism (187/95) isolated from the naturally infected laying hens was $H$. alvei. The bacterium could be distinguished from other pathogens $(11,17)$ that have been reported to be similar. The size and characteristics of the $H$. alvei colonies on MacConkey agar closely resemble those of Salmonella spp. The isolated organism may grow on highly selective isolation media such as Salmonella-Shigella agar (17), but $H$. alvei fails to produce $\mathrm{H}_{2} \mathrm{~S}$ on TSI and SIM agar. Salmonella cholerasuis subsp. IV, Salmonella bongori, and $H$. alvei can be cultured in the presence of $\mathrm{KCN}$, but the production of acid from sorbitol by these Salmonella spp. establishes their difference from $H$. alvei. When separating $H$. alvei from $E$. aerogenes, $E$. gergoviae, Serratia spp., and $E$. cloacae, the failure of $H$. alvei to ferment sorbitol and inositol is particularly useful. Hafnia alvei can be separated from $Y$. regensburgei by citrate utilization and acid production from melibiose and glycerol (17). Because the organism that can cause more confusion is Salmonella spp., the API 20E system was a useful tool as a first diagnostic step and the Hafnia-specific bacteriophage 1672 provided the final reliable and precise method for the identification and differentiation of $H$. alvei 187/95 from other bacteria (Salmonella spp.: 96/93 and 261/94, E. cloacae: 63/94, K. oxytoca: 122/96, and Yersinia sp.: $68 / 96$ ) that may cause similar clinicopathologic effects.

Hafnia alvei has been considered to be an opportunistic pathogen in numerous species $(11,17)$. However, in the present report, no predisposing factors were reported by the flock owner or by the veterinarian in charge. No other pathogen (bacteria or fungus) was found in the diseased chickens; virus infection was not investigated, with the exception of a hemagglutination inhibition test against Newcastle disease virus. However, the flock had been recently vaccinated against Newcastle disease and no characteristic Newcastle disease lesions were noted in the diseased birds. Furthermore, the experimental trial to test $H$. alvei pathogenicity resulted in very similar clinical signs as those noted in the 
naturally infected chicken with lack of appetite and depression commonly present with septicemia. The main lesions were characterized by parenchymal necrosis of the spleen and liver, as are frequently found in septicemia in hens caused by Salmonella spp. (3). The hepatic and splenic lesions were associated with intravascular bacterial colonies in naturally and experimentally infected laying hens.

The immunohistochemical methods demonstrated the association of $H$. alvei with the necrotic lesions in both naturally and experimentally infected laying hens. Thus, the immunohistochemical procedure is a useful complementary test for detecting Hafnia, especially in formalin-fixed tissues.

In conclusion, the present study reports the isolation of $H$. alvei from diseased laying hens. The isolated bacteria (187/95) caused very similar clinicopathologic effects in both naturally and experimentally infected laying hens. Because Salmonella spp. may cause a very similar disease, we stress the possibility of a misdiagnosis and advise the use of the techniques described above to establish an accurate diagnosis for $H$. alvei in such cases.

\section{REFERENCES}

1. Allen, D. A. Bacteria associated with freshwater fish farming, with emphasis on the fish pathogen, Aeromonas salmonicida. Diss. Abstr. Int. 45:3163. 1982.

2. Binde, M., and $O$. Hermansen. Hafnia alvei in mastitis secretion, a case report. Nor. Veterinaertidsskr. 94:569-570. 1982.

3. Clarke, R. C., and C. L. Gyles. Salmonella. In: Pathogenesis of bacterial infections in animals. C. $\mathrm{L}$. Gyles and Ch. O. Thoen, eds. Iowa State University Press, Ames, IA. pp. 95-109. 1986.

4. Eveland, W. C., and J. E. Faber. Antigenic studies of a group of paracolon bacteria (32011 group). J. Infect. Dis. 93:226-236. 1953.

5. Friis, N. F. Some recomendations concerning primary isolation of Mycoplasma suipneumoniae and Mycoplasma flocculare. Nord. Veterinaermed. 27: 337-339. 1975.

6. Gelev, I., E. Gelev, A. G. Steigerwalt, G. P. Carter, and D. J. Brenner. Identification of the bacterium associated with haemorrhagic septicaemia in rainbow trout as Hafnia alvei. Res. Microbiol. 141:573576. 1990.
7. Guinée, P. A. M., and J. J. Valkenburg. Diagnostic value of a Hafnia-specific bacteriophage. J. Bacteriol. 96:564. 1968.

8. Harada, K., K. Shimizu, and T. Matsuyama. Hafnia isolated from man. Gunma J. Med. Sci. 6: 109-112. 1957. [In Japanese.]

9. Harlow, E., and D. Lane. Immunizations. In: Antibodies, a laboratory manual. E. Harlow and D. Lane, eds. Cold Spring Harbor Laboratory, Cold Spring Harbor, NY. pp. 53-138. 1988.

10. Kelly, W. R. Patterns of hepatic necrosis. In: Pathology of domestic animals, vol. II, 4th ed. K. V. F. Jubb, P. C. Kennedy, and N. Palmer, eds. Academic Press, San Diego, CA. pp. 337-346. 1993.

11. Krieg, N. R., and P. H. Sneath. The genus Hafnia. In: Bergey's manual of determinative bacteriology, 9th ed. J. G. Holt, N. R. Krieg, P. H. A. Sneath, J. T. Staley, and S. T. Williams, eds. Williams \& Wilkins, Baltimore, MD. pp. 180-234. 1994.

12. Martín de las Mulas, J., A. Fernández, M. A. Sierra, J. B. Poveda, and J. Carranza. Immunohistochemical demonstration of Mycoplasma gallinarum and Mycoplasma gallinaceum in naturally infected hen oviducts. Res. Vet. Sci. 49:339345. 1990.

13. Meehan, J. T., K. A. Bragden, C. Courtney, R. C. Cutlip, and H. D. Lehmkuhl. Chronic proliferative rhinitis associated with Salmonella arizonae in sheep. Vet. Pathol. 29:556-559. 1992.

14. Mukherjee, S. R., A. M. Das, V. L. Paranjape, and S. R. Marwah. Hafnia alvei isolated from an equine aborted foetus. Indian J. Vet. Med. 6:101102. 1986.

15. Refaie, R. S., A. A. Abou, M. A. Seham, and A. M. Sayed. Microbiological quality of suspected corned beef in Assiut. Assiut Vet. Med. J. 28:205210. 1993.

16. Ridell, C. Bacterial hepatitis. In: Avian histopathology, 1st ed. American Association of Avian Pathologists, eds. Allen Press, Lawrence, KS. p. 61. 1987.

17. Sakazaki, R., and K. Tamura. The genus Hafnia. In: The prokaryotes, 2nd ed., vol. 1. A. Balows, H. G. Trüper, M. Dworkin, W. Harder, and K. Schleifer, eds. Springer-Verlag, New York, NY. pp. 2816-2821. 1992.

18. Salimov, R. M. Hafnia strains isolated from honey. Veterinaria, 4:44-46. 1978.

19. Sharma, R. K., B. R. Boro, and P. Borah. Incidence of caprine pneumonia and associated bacterial species. Indian J. Anim. Sci. 61:54-55. 1991.

20. Smibert, R. M., and N. R. Krieg. Systematics: general characterization. In: Manual of methods for general bacteriology. P. Herhardt, R. G. E. Murray, R. N. Costilow, E. W. Nester, N. A. Wood, N. R. Krieg, and G. B. Phillips, eds. American Society for Microbiology, Washington, DC. pp. 409-443. 1981. 
21. Texdorf, V. I., G. Kielwein, and E. Ergüllü. Differentiation of enterobacteria isolated from milk. Arch. Lebensmittelhyg. 26:46-49. 1975.

22. Tornadijo, E., J. M. Fresno, J. Carballo, and R. Martin. Study of Enterobacteriaceae throughout the manufacturing and ripening of hard goats' cheese. J. Appl. Bacteriol. 75:240-246. 1993.

23. Whitcomb, R. F. Culture media for spiroplasmas. In: Methods in mycoplasmology, vol. I. S. Razin and J. G. Tully, eds. Academic Press, New York, NY. pp. 159-162. 1983.
24. Ximena, M. V., and T. M. Oriele. Hafnia alvei aislada en un caso de aborto equino. Arch. Med. Vet. 15:90-91. 1983.

\section{ACKNOWLEDGMENT}

We greatly thank Dr. Juan José Borrego of the University of Málaga, Spain, for all the help that he gave us in developing this research. 